\title{
PENYELESAIAN KREDIT MACET MELALUI UPAYA LITIGASI DI KOPERASI SIMPAN PINJAM SURYA MANDIRI DI KABUPATEN GIANYAR
}

\author{
I Putu Surya, I Nyoman Sukandia, Ni Komang Arini Styawati \\ Fakultas Hukum Universitas Warmadewa, Denpasar-Bali, Indonesia \\ putusurya2227@gmail.com, arinistyawati@gmail.com
}

\begin{abstract}
Abstrak
Perkembangan perekonomian di era globalisasi semakin meningkat, masalah keuangan yang menjadi persolan serius. Salah satu solusi untuk membantu keuangan keluarga dengan mengambil kredit atau pinjaman. Penelitian ini bertujuan untuk menelaah faktor-faktor apakah yang menyebabkan terjadinya kredit macet di Koperasi Simpan Pinjam Surya Mandiri di Kabupaten Gianyar dan mengkaji upaya penyelesian kredit macet melalui jalur litigasi di Koperasi Simpan Pinjam Surya Mandiri di Kabupaten Gianyar. Tipe penelitian yang digunakan Hukum Empiris dengan dengan pendekatan kasus masalahnya secara konseptual dan sosiologis yang dilakukan pada KSP SURYA MANDIRI di Kabupaten Gianyar. Adapun sumber data yang digunakan yaitu data primer dan sekunder yang diperoleh melalui tenik pencatatan dan wawancara. Hasil penelitian menunjukkan bahwa faktor-faktor yang menyebabkan terjadinya kredit macet pada koperasi ialah faktor internal merupakan faktor penyebab kredit macet yang berasal dari pihak koperasi itu sendiri, Faktor ekternal merupakan faktor penyebab kredit macet yang berasal dari pihak nasabah. Penyelesaiain kredit macet ditempuh melalui non-litigasi dan litigasi.
\end{abstract}

Kata Kunci : Koperasi Simpan Pinjam, Penyelesaian Kredit Macet, Upaya Litigasi

\begin{abstract}
Economic developmentin era globalization increasing, with finance becoming necessity for every human being. research problems are: What factors cause bad credit at Surya Mandiri Savings and Loans Cooperative Gianyar Regency and how bad credit settlement efforts through litigation at Surya Mandiri Savings and Loan Cooperative Gianyar Regency This type research used Empirical Law. the factors that cause bad credit in cooperatives are internal factors that cause bad credit originating from the cooperative itself, external factors are factors that cause bad credit originating from customer side. Non-litigation is settlement of disputes outside the court that closed to public and the confidentiality of the parties guaranteed. Litigation dispute resolution is dispute resolution carried out through the court. It can be concluded that factors that cause bad credit at Surya Mandiri Savings and Loan Cooperative in Gianyar Regency are internal factors and external factors. The settlement of bad credit at Surya Mandiri Savings and Loan Cooperative in Gianyar Regency can be done by non-litigation and litigation. should not only pursue profit, but must be more assertive and apply the principle of prudence and Head of the cooperative credit department must be more careful providing loans to borrowers.
\end{abstract}

Keywords : Credit Settlement, Litigation Efforts, Savings, Loan Cooperatives

\section{PENDAHULUN}

Semakin bertambahnya penduduk akan membuat manusia untuk semakin berjuang mendapatkan uang dari hasil kerja kerasnya. Namun, apabila hasil kerja keras masih dianggap belum mampu untuk memenuhi kebutuhan hidup mereka, maka perusahaan dianggap yang bisa membantu untuk memberikan fasilitas pinjaman atau kredit kepada masyarakat demi memenuhi kelangsungan hidup yang dianggap kurang dan demi menambah kecukupan akan modal usaha. Salah satu solusi untuk membantu pendiri usaha pemula yang tidak memiliki modal dengan melakukan peminjaman modal atau kredit (Abdul Latif \& Ayatullah, 2018).

Koperasi sebagai salah satu lembaga keuangan yang berada di tengah-tengah masyarakat diharapkan dapat menunjang setiap hal yang diharapkan oleh kalangan masyarakat kecil menengah dalam memperoleh kredit untuk menjalankan usahanya. Sesuai dengan ketentuan dalam internal koperasi, koperasi harus bisa menyalurkan kredit untuk mengimbangi pengembalian bunga tabungan dan deposito yang masyarakat tempatkan (Teguh et al., 2004). Koperasi yang berbaur di kalangan masyarakat saat ini dan tidak hanya satu atau dua lembaga koperasi saja tetapi hampir disetiap desa ada yang mendirikan koperasi karena tidak banyak ketentuan atau persyaratan saat pendirian, hal ini 
yang membedakan keistimewaan koperasi dengan lembaga keuangan lainnya. Sehingga banyak dari orang-orang yang sudah menjadi pejabat eksekutif atau memiliki jabatan di lembaga keuangan lain, mereka bisa mendirikan Koperasi dan memanfaatkan lulusan terbaik untuk menunjang semua usahanya.

Masyarakat dalam memperoleh pinjaman di suatu lembaga keuangan ataupun non lembaga keuangan, misalnya masyarakat ingin mengajukan pinjaman di Koperasi untuk dapat melanjutkan usahanya, masyarakat hanya perlu menjadi anggota di Koperasi bersangkutan untuk mempermudah kredit tersebut dibantu. Pihak Koperasi sebagai salah satu penyalur pinjaman dalam bentuk kredit harus memenuhi ketentuan yang berlaku. Seiring berkembangnya jaman pada era globalisasi dan perkembangan ekonomi semakin tinggi, khususnya pada bidang keuangan yang menjadi keperluan guna memenuhi kehidupan manusia. Pada hakikatnya pemberian kredit dapat diberikan kepada siapa saja yang mempunyai kesanggupan melakukan perjanjian hutang piutang antara kreditur dan debitur (S.Gazali, 2010). Sesuai dengan prinsip koperasi sebagai lembaga keungan dalam menyalurkan kredit kepada masyarakat, pihak koperasi perlu menekankan prinsip kehati-hatian dalam menjalankan usahanya sebagai penyalur kredit, tabungan dan deposito. Selain itu untuk menentukan koperasi itu berhasil dalm dunia bisnis tentu saja harus mengajak sebanyak-banyaknya masyarakat untuk bergabung menjadi anggota koperasi. Hal ini tentu saja mendukung perkembangan usaha Koperasi di lingkungan masyarakat dan semakin menambah keuntungan yang diperoleh yang bisa dijadikan patokan untuk memberikan gaji kepada karyawan yang berperan dalam mempromosikan setiap produk yang dimiliki.

Usaha koperasi yang dijalankan oleh pemilik dan diabntu oleh seluruh karyawan yang ada didalamnya untuk meningkatkan usahanya, pihak koperasi tentu saja harus melakukan seleksi terhadap karyawan yang memiliki kemampuan sesuai dengan jurusan yang telah diambil di bangku kuliah. Pemilik harus bisa mengimbangi antara modal yang dimiliki dengan penyaluran kredit yang akan diberikan kepada para anggota. Koperasi mempunyai peran sangat penting yaitu menumbuhkan dan mengembangkan ekonomi untuk mewujudkan kehidupan ekonomi yang demokratis, kekeluargaan, dan keterbukaan (Handikusuma, 2000). Prinsip perkoperasian tidak banyak berbeda, yaitu anggota bersifat sukarela dan terbuka, pengelolaannya dilaksanakan secara demokratis, pembagian sisa hasil usaha diberlakukan secara adil dan seimbang dengan jasa usaha masing-masing (Untung, 2005).

Pertumbuhan usaha koperasi tergantung dari keseriusan para pengelola dan pengawas koperasi dalam melaksanakan penyaluran kredit kepada masyarakat. Para pengelola, baik itu manager, kepala bagian dan seluruh staf harus memiliki integritas untuk meningkatkan kinerja sesuai dengan harapan pengawas untuk mendapatkan hasil yang bisa membawa koperasi itu sendiri ke arah kemajuan baik dari segi permodalan, penyaluran kredit dan meningkatkan tafar hidup seluh karyawan. Seiring meningkatnya kegiatan koperasi jika diperhatikan dari jumlah anggota koperasi seberapa banyak aliran uang yang telah memfasilitasi anggotanya. Sudah banyak koperasi yang gagal dan mengalami penutupan dikarenakan kecerobohan dari dalam koperasi, kurangnya anggota yang bergabung dan tidak berbanding antara pengeluaran kredit dan pemasukan dana berupa tabungan maupun pembayaran kredit.

Meningkatkan kinerja khususnya dalam penyaluran kredit kepada masyarakat menengah atau kalangan atas harus sesuai dengan ketentuan yang berlaku dalam Koperasi itu sendiri, tidak hanya mengejar keuntungan tetapi karyawan harus bisa menganalisa situasi nasabah sebelum membatu kredit tersebut. Pihak koperasi perlu mempunyai prinsip independen dalam hal menyalurakan dana demi menghindari terjadinya kredit macet yang membuat kerugian yang begitu besar kedepannya. Dalam hal ini dikemukakan contoh kasus Koperasi Simpan Pinjam Surya Mandiri dapat disebut sebagai pihak kreditur ketika berhak menerima pembayaran sejumlah uang dari nasabah yang melakukan kredit atas pinjaman yang telah diberikan dari pihak Koperasi Simpan Pinjam Surya Mandiri yang sesuai dengan kesepakatan atau perjanjian yang sudah di sepakati. Pihak kedua disebut sebagai kreditur Ketika berhak menerima sejumlah uang atas kredit yang diberikan. Sebelum dilakukan perjanjian wajib ada perjanjian antara kedua belah pihak. Apabila nanti setelah kredit itu diberikan ada salah satu pihak yang mengingkari maka dapat dikatakan perjanjian itu wanprestasi (ingkar janji). 
Jika tidak memperhatikan prinsip kehati-hatian akan mengakibatkan risiko kredit macet. Untuk menjamin kepastian masing-masing pihak baik antara kreditur dan debitur sangat perlu adanya aturan dalam semua lembaga perkoperasian sehingga apabila terjadi hal-hal yang tidak diinginkan maka tidak ada pihak yang dirugikan. Hal ini juga mendukung perkembangan setiap usaha Koperasi kedepannya, apalagi sekarang sedang berkembangnya media sosial yang dapat dimanfaatkan untuk melakukan promosi, sehingga itu bisa dikatakan kualitas sumber daya manusia harus sesuai dengan harapan.

Setiap usaha yang dijalankan oleh pemilik koperasi pasti memiliki dampak positif dan negatif yang dapat mempengaruhi permodalan koperasi kedepannya. Maka dari itu sebelum mengarah ke kredit macet, sangat perlu diambil langkah-langkah secepatnya untuk melakukan penyelamatan kredit. Dalam hal ini pengurus koperasi juga perlu melakukan review terhadap ketentuan dan aturan yang berlaku di internal koperasi itu sendiri. Apakah aturan yang dibuat sudah dijalankan atau diindahkan demi meningkatkan jumlah kredit yang tidak sesuai ketentuan. Inilah menjadi tantangan dari pemilik untuk tetap mengawasi, mengarahkan, memantau, dan memeriksa setiap ketentuan yang sudah asda dan yang akan diperbaharui. Penelitian terdahulu mengungkapkan Penyebab terjadinya kredit macet pada koperasi simpan karena adanya kegagalan atau musibah yang menimpa perusahaan atau usaha nasabah sehingga membuat debitur menjadi rugi sehingga pembayaran kredit dari nasabah, j ika ada masalah kemacetan krdari nasabah maka bisa diselesaikan melaui litigasi dan non litigasi (Sari et al., 2019) \& (Suarjaya, 2015). Berdasarkan uraian di atas maka, penelitian ini dilakukan dengan tujuan menelaah faktor- faktor apakah yang menyebabkan terjadinya kredit macet di Koperasi Simpan Pinjam Surya Mandiri di Kabupaten Gianyar dan mengkaji upaya penyelesian kredit macet melalui jalur litigasi di Koperasi Simpan Pinjam Surya Mandiri di Kabupaten Gianyar

\section{METODE PENELITIAN}

Penelitian ini didesain menggunakan penelitian hukum empiris, dengan pendekatan kasus masalahnya secara konseptual dan sosiologis yang dilakukan pada Ksp Surya Mandiri di Kabupaten Gianyar. Data primer yaitu data lapangan, data yang diperoleh di lokasi penelitian yaitu pada KSP Surya Mandiri di Kabupatren Gianyar yang ada hubungannya dengan materi yang akan dibahas dalam penelitian ini yaitu mengenai masalah penyelesaian kredit macet melalui upaya litigasi pada KSP Surya Mandiri di Kabupaten Gianyar. Data sekunder yaitu dari kepustakaan, data yang diperoleh dengan mempelajari buku-buku literatur yang sesuai atau berkaitan dengan permasalahan yang dibahas sehingga data yang telah terkumpul dijadikan sebagai landasan teori maupun penjelasan atau pelengkap. Pengumpulan data primer yang digunakan adalah dengan teknik wawancara yaitu menggunakan pedoman pertanyaan atau interview kepada informan yang dapat memberi penjelasan mengenai permasalahn yang dihadapi. Setelah data-data yang dibutuhkan terkumpul, maka data tersebut selanjutnya diolah dan dianalisis dengan mengunakan teknik pengolahan data secara kualitatif sesuai dengan fakta yang terjadi di lapangan secara bermutu dalam bentuk kalimat yang teratur, logis, runtun dan tidak saling tumpang tindih yang nantinya akan mempermudah pemahaman (Sugiyono, 2005).

\section{HASIL DAN PEMBAHASAN}

\section{Faktor-faktor yang Menyebabkan Terjadinya Kredit Macet di Koperasi Simpan Pinjam Surya Mandiri di Kabupaten Gianyar}

Setiap lembaga bank maupun non bank yang memberikan kredit kepada debitur, tentunya mempunyai harapan bahwa kredit yang mereka berikan akan kembali tepat waktu. Pada hakikatnya sering ada nasabah yang tidak dapat mengembalikan pinjaman kredit dan apalagi jika melihat kondisi debitur juga yang mempunyai usaha pasang surut dengan itu debitur mengalamin kesusahan buat mengembalikan pinjaman kepada koperasi sebagai pihak kreditur. Setiap koperasi pasti mengalami kredit bermasalah, kredit bermasalah sebetulnya membicarakan akibat yang terkandung dalam setiap pemberian kredit, dengan itu dapat diyakinkan bahwa koperasi bisa jadi terlepas dari kredit bermasalah. Kredit bermasalah dapat disebabkan oleh berbagai faktor, misalnya adanya ketakseimbangan oleh pihak-pihak yang terlibat dalam proses pemberian kredit, kesalahan prosedur 
pemberian kredit, atau dikarenakan oleh faktor lain seperti faktor makro ekonomi (Hermansyah, 2014).

Kredit bermasalah adalah suatu peminjaman kredit koperasi yang dilakukan oleh nasabah koperasi sebagai debitur tetapi pelunasannya mengalami ketidak lancaran yang ditimbulkan oleh pihak debitur sendiri, bisa saja kna bencana alam yang mengakibatkan usaha debitur mengalami kendala akibat kerusakan lingkungan. Pihak koperasi sebagai kreditur harus teliti dan menganalisis terlebih dahulu apakah kredit yang akan diberikan tersebut layak atau tidak untuk diberikan kepada debitur guna memungkiri menimbulkan kredit bermasalah di kemudian hari. Sehingga sangat perlu pemahaman dan analisis yang kuat dari kepala bagian kredit dan karyawan yang ditunjuk di bagian kredit untuk melakukan analisa baik dari segi karakter, kemapuan bayar dan usaha yang sedang berkembang.

Menurut I Wayan Nasib, selaku pengawas di KSP. Surya Mandiri, didalam memperhatikan standar kredit bermasalah di KSP. Surya Mandiri terlebih menirukan pengelompokan yang sudah diterapkan pada bank umum jadi tidak ada pengelompokan tertentu yang merupakan petunjuk untuk melihat apakah kredit tersebut dinyatakan bermasalah. Seharusnya apabila kredit yang dicairkan tidak ada unsur kekeluargaan yang mengharuskan kredit tersebut dibantu, sebagai pengurus koperasi I Wayan Nasib mengatakan prinsip kehati-hatian dan profesional harus diterapkan dalam memberikan kredit kepada anggota koperasi sehingga hal ini bisa menekan terjadinya ingkar janji saat kredit tersebut sudah dicairkan oleh pihak koperasi. Tidak hanya itu salah satu yang membuat koperasi itu tidak berkembang adalah kurangnya pengawasan dari pemilik dan hanya mengandalkan kinerja bawahannya saja.

Wayan Balik Wiadnyana, sebagai Kepala Bagian Kredit di KSP. Surya Mandiri menerangkan, bila kredit dinyatakan sudah mulai bermasalah, dapat dilihat dari kolektibilitas kredit yang diawali dari lancar, kurang lancar, diragukan dan macet. Bilamana kredit bermasalah diabaikan terus menerus akan berakibat pada kesenjangan hidup suatu usaha perkoperasian. Seperti koperasi tidak bisa melaksanakan tanggung jawabnya sehingga mengakibatkan kerugian secara perlahan, serta tidak ada pendapatan atau penghasilan dari bunga kredit koperasi itu sendiri untuk menunjang berjalannya operasional koperasi kedepannya.

Hasil wawancara dengan I Kadek Hadi Sumarna selaku manajer KSP. Surya Mandiri, faktor internal yang mengakibatkan timbulnya kredit macet adalah kurangnya kemampuan pegawai khususnya di bagian analisa kredit dalam mencari informasi baik informasi dari karakter, agunan, kemapuan bayar, dan kondisi ekonomi nasabah. Selain itu faktor lain sebagai penyebab yaitu masih lemahnya pengawasan dalam pengikatan jaminan kredit, sehingga apabila dalam pencairan kredit tidak dilakukan pengikatan agunan nantinya pihak koperasi sulit melakukan eksekusi saat kredit mengalami tunggakan pembayaran dan timbul kredit macet. Kemudian dari hasil wawancara dengan Bapak I Wayan Balik Wiadnyana sebagai kepala bagian kredit Koperasi Surya Mandiri di jelaskan bahwa ada juga faktor- faktor ekternal yang mempengaruhi pemberian kredit. Faktor eksternal dapat dikatakan baik jika perekonomi masyarakat juga membaik. Andaikan tingkat kenyamanaan masyarakat meningkat, bahwa diinginkan akan semakin tingginya permintaan penawaran pinjaman dan tabungan oleh masyarakat kepada Koperasi memiliki pengaruh yang positif terhadap pemberian kredit.

Dari hasil wawancara dengan pengawas dan Kepala Bagian Kredit KSP. Surya Mandiri, faktor eksternal menyebabkan terjadinya kredit macet di Koperasi Simpan Pinjam Surya mandiri adalah menjurus diakibatkan dari faktor nasabah yakni :

1. Adanya kegagalan yang menimpa perusahaan atau usaha nasabah terus mengakibatkan debitur menjadi rugi dan berimbas kepada pembayaran kredit yang telah berlangsung sebab, jika nasabah tersebut mengalami kegagalan atau musibah mengakibatkan penghasilan debitur menjadi menurun yang dikarenakan oleh tanggungan beban kerugian.

2. Adanya pademi covid 19 yang mengakibatkan terjadinya penurunan ekonomi di dalam usaha anggota koperasi yang meminjam kredit karena ada peraturan perbatasan jam kerja.

3. Beberapa anggota di KSP Surya Mandiri sebagian bekerja menjadi buruh, petani, dan nelayan. Pendapatan mereka dapat dikatakan rendah dan kurang mencukupi Bilamana tidak terdapat musim kerja mereka akan mengakibatkan krisis keuangan, sehingga berdampak kepada kredit 
yang dipinjam akibat tidak dapat melunasi kredit sesuai dengan waktu yang ditentukan dan akan mengakibatkan kredit itu bermasalah.

\section{Penyelesaian Kredit Macet Melalui Jalur Litigasi di Koperasi Simpan Pinjam Surya Mandiri di Kabupaten Gianyar}

Non-litigasi adalah penyelesaian perkara di luar pengadilan bersifat tertutup dan kerahasiaan para pihak dijamin. Proses penyelesaian perkara di luar pengadilan ini menghindari kelambatan yang di akibatkan procedural dan administrative sebagaimana beracara di pengadilan umum dan win-win solution. (Adolf, 2002). Langkah-langkah untuk mencapai penyelesaian kredit bermasalah tersebut dengan cara yang saling menguntungkan, kredit yang dapat diselesaikan dengan musyawarah mufakat adalah kredit yang belum menginjak ke kredit macet, sehingga bisa lebih mudah untuk memberikan kebijakan dalam hal melakukan penjualan agunan atau diperbaiki hingga kualitas kredit tersebut tergolong kredit lancar dan dapat dilakukan pembinaan setiap bulannya untuk menghindari terjadi lagi tunggakan akibat dari keterlambatan pembayaran kredit dari waktu yang ditetapkan.

Sebagai tindak lanjut dari penanganan kredit macet pihak koperasi hanya perlu menekankan dan membuat nasabah tersebut melakukan tindakan yang bisa berdampak baik bagi kedua belah pihak. Misalnya dengan memberikan peringatan kepada debitur yang telah mengalami tunggakan pembayaran sebelum terjadinya kredit kurang lancar yang berdampak pada usaha koperasi. Kredit yang kurang lancar seharusnya bisa dibina dan dicarikan solusi terbaik sehingga bisa dilakukan pelunasan sebelum terjadi kredit macet dan mengarah ke jalur litigasi.

Penanganan kredit bermasalah dengan upaya litigasi yaitu jalan terakhir dari koperasi untuk melalukan upaya pengembalian kredit debitur baik dengan melakukan upaya eksekusi agunan kredit, pengambil-alihan agunan kredit oleh koperasi. Dalam hal penanganan kredit bermasalah melalui jalur non litigasi sudah tidak dapat lagi dipergunakan, maka koperasi dapat melaksanakan penanganan kredit melalui jalur litigasi hal ini bila koperasi sudah menentukan diri agar tidak lagi membangun hubungan usaha terhadap debitur, maka mata rantai hubungan usaha antara koperasi terhadap debitur telah terputus. Didalam menentukan penanganan litigasi, koperasi harus memikirkan dengan benar-benar faktor efektivitas serta efisiensi waktu serta biaya. Penyelesaian litigasi ini di pilih karena dalam hal penyelesaian secara non litigasi tidak dapat terselesaikan hingga menempuh cara ini agar kredit tersebut lunas. Sehingga penyelesaian secara litigasi sebagai pilihan terakhir dikala koperasi sudah tidak berhasil menemukan penyelesaian di luar pengadilan dan debitur juga tidak ada itikad baik dalam hal penyelesaian kredit macet tersebut sehingga langkah akhir ini dipilih oleh pihak koperasi untuk menyelesaikan kredit macet yang menimbulkan kerugian pada usaha koperasi kedepannya.

Contoh Kasus: Setiap perusahaan yang bergerak di bidang termasuk di dalam hal ini Koperasi Simpan Pinjam Surya Mandiri mencari keuntungan dengan cara meminjamkan kredit kepada nasabah. Menurut pengakuan dari manager Koperasi Surya Mandiri yakni I Kadek Hadi Sumarna, dalam memberikan pinjaman sering juga mengalami kendala-kendala yang paling sering ditemukan ialah masalah kredit macet. Padahal sebelumnya koperasi memberikan pinjaman kepada anggota koperasi terlebih dahulu sudah membuat perjanjian-perjnajian dimana isi perjanjian tersebut telah disepakati oleh kedua belah pihak dengan menandatangani surat perjanjian kredit. Dalam hal ini anggota koperasi meminjam uang sejumlah Rp.80.000.000,- jangka waktu 72 bulan (6 tahun), dengan bunga $20,40 \%$ pertahun $(1,7 \%$ perbulan) dengan kesepakatan tiap bulan debitur membayar pokok dan bunga. Namun setelah 3 bulan sejak penandatangan perjanjian kredit, debitur sudah menunjukan penurunan kemampuan pembayaran pinjaman karena dalam hal ini selalu tidak tepat jadwal. pihak koperasi telah melakukan upaya pembinaan dan teguran kepada debitur melalui Surat Pemberitahuan, Surat Peringatan I (SP I), Surat Peringatan II, Surat Peringatan III . Lalu Pihak KSP Surya Mandiri mengajukan Gugatan Sederhana ke Pengadilan Negeri Gianyar dengan Nomor Permohonan 016/KSM-ADM/XI/2019 Tertanggal 13 Nopember 2019.

Berlandaskan penjabaran di atas dengan segala kerendahan hati Penggugat memohon kepada yang terhormat Ketua Pengadilan Negeri Gianyar atau Majelis Hakim yang menyidangkan perkara ini berkenan menjatuhkan putusan. Sesuai dengan hasil Putusan Pengadilan Negeri Gianyar Nomor : 6/Pdt.G.S/2019/PN Gin. Tertanggal 12 Desember 2019. Pasal 2 dijelaskan bahwa pihak Tergugat 
telah mengakui dan sanggup untuk membayar pinjaman yaitu utang milik Penggugat sebesar Rp. 115.254.000,- sesuai dengan perincian hutang yaitu Pokok sebesar Rp. 76.895.500,- Bunga sebesar Rp. 35.102.500,- dan Denda sebesar Rp. 3.256.000,- yang akan dibayar dengan jangka waktu selama 6 (enam) bulan terhitung sejak tanggal 15 Desember 2019 sampai dengan tanggal 15 Mei 2020.

Putusan Nomor 6/Pdt.G.S/2019/PN Gin Demi Keadilan Berdasarkan Ketuhanan Yang Maha Esa Mengadili :Menghukum Penggugat dan Tergugat untuk mentaati dan melaksanakan isi dari Kesepakatan Perdamaian yang telah disetujui tersebut, menghukum Penggugat untuk membayar biaya perkara sebesar Rp. 366.000. Dari turunan putusan Pengadilan Negeri Gianyar pihak Tergugat mengikuti isi putusan tersebut dengan itikad baik walaupun tidak sesuai dengan ketentuan pelunasan per tanggal 15 Mei 2020, tetapi pihak Tergugat melakukan pelunasan pada tanggal 21 Desember 2020. Walaupun jalur litigasi jarang ditempuh tetapi jalur litigasi bisa membantu untuk menyelesaikan kredit macet tanpa adanya tindak kekerasan antara penggugat dan tergugat.

\section{SIMPULAN DAN SARAN}

\section{Simpulan}

Berdasarakan hasil pembahsan tersebut di atas, dapat disimpulkan bahwa Faktor-faktor yang menyebabkan terjadinya kredit macet di Koperasi Simpan Pinjam Surya Mandiri di Kabupaten Gianyar yakni faktor internal yang mempengaruhi kredit macet yaitu rendahnya kemampuan pihak koperasi dalam melakukan analisa kredit, lemahnya sistem dalam pengikatan jaminan kredit, dan masih mementingkan unsur kekerabatan yang berlebihan sehingga mengesampingkan aturan-aturan yang berlaku. Faktor ekternal yang mempengaruhi kredit macet yaitu terjadinya penurunan pendapatan nasabah, adanya musibah yang menimpa nasabah atau perusahaan nasabah, dan adanya dampak dari wabah virus covid 19 yang berpengaruh pada pendapatan nasabah. Penyelesian kredit macet pada Koperasi Simpan Pinjam Surya Mandiri di Kabupaten Gianyar bisa dilakukan secara non litigasi seperti negosiasi, mediasi, konsiliasi dan arbitrase dan secara litigasi melalui jalur pengadilan seperti kasus Putusan Pengadilan Negeri Gianyar Nomor 6/Pdt.G.S/2019/PN Gin. Bahwa Pengadilan menghukum Penggugat dan Tergugat untuk mentaati dan melaksanakan isi dari kesepakatan perdamaian yang telah disetujui tersebut dan menghukum Penggugat untuk membayar biaya perkara.

\section{Saran}

Berdasarkan hasil simpulan tersebut di atas adapun saran yaitu diharapkan kepada Koperasi Simpan Pinjam Surya Mandiri di Kabupaten Gianyar seharusnya tidak hanya mengejar keuntungan, tetapi harus lebih tegas dan menerapkan prinsip kehati-hatian dalam menyetujui pemberian kredit yang nantinya bisa membuat perusahan mengalami kerugian dan memberikan pembinaan kepada nasabah agar memenuhi kewajibanan setiap bulannya, agar tidak terjadi kembali kredit macet serta memeriksa secara detail semua data nasabah. Kepala Bagian Kredit Koperasi Simpan Pinjam Surya Mandiri di Kabupaten Gianyar harus lebih hati-hati dalam memberikan pinjaman kepada debitur, harus mengutamakan Prinsip 5C dalam penyaluran kredit dan lebih tegas dalam melakukan control kepada karyawan koperasi dalam melakukan tindak lanjut dalam menyelesaikan kredit macet. Sedangkan bagi pihak debitur, hendaknya berhati-hati dalam penandatanganan perjanjian kredit yang diberikan oleh pihak koperasi dengan cara membaca dan mengerti isi perjanjian kredit yang belum dimengerti supaya tidak ada kesalah pahaman di kemudian mengenai isi perjanjian kredit tersebut.

\section{DAFTAR PUSTAKA}

Abdul Latif, \& Ayatullah. (2018). Dampak Kredit Modal Terhadap Peningkatan Usaha Pedagang Kecil di Pasar Sentral Kota Gorontalo. Journal of Chemical Information and Modeling, 14(2), 90-111.

Adolf, H. (2002). Hukum Penyelesaian Sengketa Internasional. Jakarta. Sinar Grafika. Handikusuma, R. (2000). Hukum Koperasi Indonesia. Jakarta. PT. Raja Grafindo. Hermansyah. (2014). Kepastian Hukum dalam Penyelesaian Kredit Bermasalah. Kencana. S.Gazali, D. (2010). Pengerti dan Dasar Hukum Perbankan. Jakarta. Sinar Grafika.

Sari, N. L. A. S. H., Indrawati, A. A. S., \& Putrawan, S. (2019). Penyelesaian Kredit Macet Pada Koperasi Simpan Pinjam Karya Artha Sedana dan Ksp. Wirartha Utama di kota Denpasar Selatan. Journal Ilmu Hukum, 7(8), 1-17. 
Suarjaya, I. N. (2015). Analisis Penanganan Kredit Macet pada Koperasi Pasar Srinadi Klungkung. Jurnal Akuntansi Dan Pendidikan, 5(1), 11--19.

Sugiyono. (2005). MemahamiPenelitian Kualitatif. Bandung: Alfabeta.

Teguh, M., Chodijah, R., \& Rosyita, N. (2004). Pengaruh Tingkat Bunga dan Penghimpunan Dana Terhadap Kredit Perbankan di Indonesia. Jurnal Ekonomi Pembangunan, 2(2), 85-102.

Untung, H. B. (2005). Hukum Koperasi dan Peran Notaris Indonesia. Andi. Yogyakarta. 